\title{
"In Another Kind of Wood": Michel Foucault and Sociolegal Studies
}

Jonathan Simon

When Michel Foucault died on 24 June 1984, the interest in his work outside of his native France was only beginning its rise, and it is far from clear whether it has peaked. What Auden wrote of Yeats on his death might apply as well to the posthumous career of Michel Foucault:

Now he is scattered among a hundred cities

And wholly given over to unfamiliar affections;

To find his happiness in another kind of wood

And be punished under a foreign code of conscience.

The words of a dead man

Are modified in the guts of the living. ${ }^{1}$

The exegetical struggles that have broken out over what Foucault meant by his words, acts, and associations will doubtless go on and on. It is a welcome sign that another kind of discourse rooted in Foucault's work has also begun to emerge, one aimed not at defining that work but continuing it. It is obvious that exegesis of a great thinker and the research which she provokes remain bound together, but the stance toward the work which one takes in each differs. Working to constitute and reconstitute the logic(s) of a body of work draws one into the sensibility of the museum curator; generally an ethos of reverence or rebellion. The appropriation of the same work by researchers has more in common with the credos of grave robbery; get in quietly, grab what looks most valuable (with

Jonathan Simon is an assistant professor of political science at the University of

1. The Collected Poetry of W. H. Auden 49 (New York: Random House, 1945). 
no concern for the ritual significance of the objects), get out and back to the marketplace fast.

Alan Hunt's essay in this issue ${ }^{2}$ does rather an impressive exegetical job of bringing together the most important statements of Foucault on law, but its spirit is also very much in the research camp (at least that's the aspect of it I most respond to). Texts get parsed, but largely in the name of helping us think more critically about Foucault's substantive and methodological contributions to the research agenda of sociolegal studies. The point is not to "recover" Foucault's understanding of law but to see how a more adequate understanding of law might refocus Foucault's analysis of power in modern society-what Hunt usefully calls a "retrieval" of law.

The core of this retrieval, the reconceptualization of the relationship between law and discipline, is extremely useful in opening up research questions for sociolegal scholars who have been provoked by Foucault's analysis of disciplinary power, and for directing research in cultural studies that has been inspired by Foucault to look more closely at law. To this aspect of Hunt's retrieval I wish to add only a brief twist by asking how we might make sense of Foucault's mistaken view.

Hunt also points to the gap between Foucault's persuasive micro analyses of power and his less plausible (and seemingly self-contradictory) global descriptions of modern society. I want to briefly contest Hunt's call for bringing interest, the state, and hegemony in to fill this gap. Dealing with this gap is crucial in appropriating Foucault, but taken somewhat differently, his apparent failure to analyze larger institutional and state structures of power might point us to a new and useful way of exploring what used to be called the "middle range."

Foucault's famous analysis of disciplinary power has been provocative to legal scholars, but the stark opposition he sets up between law and discipline has also confounded those who see law as playing more than an epiphenomenal role. Hunt argues persuasively that disciplinary power relations in modern society actually interact with law in a complex set of ways not captured by the model of displacement. Discipline has created new functions and incitements to legalization. Law in turn has opened new sites to the development of disciplines. This is a terribly important point for sociolegal research. If one stays with Foucault's pronouncements in Discipline and Punish, it looks like law plays a role primarily as an ideology which serves to cover up the transformation in the way power is being exercised in modern society. ${ }^{3}$ If we stop there, we can make little sense, from Foucault's perspective, of the ferocious activity around legal rules

2. Alan Hunt, "Foucault's Expulsion of Law: Toward a Retrieval," 17 Law $\mathcal{E}$ Soc. Inquiry 1 (1992).

3. Trans. Alan Sheridan (New York: Pantheon Books, 1977). Already this is an interesting alternative to a more classically Marxian analysis of law as ideology in which law covers up relative power. 
that govern power relations in work, the professions, and the family during the late 19th and 20th centuries. ${ }^{4}$

Retrieving law in this sense, however, continues to leave the question of what Foucault had in mind in so strongly insisting on the opposition of law and discipline. Rhetorical reasons cannot be dismissed, but it is also possible that the law Foucault describes as displaced by the emergence of disciplinary powers is not the same law that proliferates alongside discipline. Consider Roscoe Pound's characterization of three senses in which scholars speak of law:

(A) What is better called the legal order, that is, the regime of adjusting relations and ordering conduct by the systematic application of the force of a politically organized society; (B) the authoritative grounds of or guides to determination of disputes in such a society-a body of authoritative precepts, developed and applied by such an authoritative technique in the light or on the background of authoritative traditional ideals; and (C) ... the judicial process, to which we must add the administrative process. ${ }^{5}$

In linking law to the premodern regime of power-sovereignty or "juridical power" as he sometimes called it-Foucault seemed to have in mind something like Pound's second category, that is, the way law has operated as a kind of official political theory of Western nation states. Hunt's contention that legal institutions and discourses rather than disappearing have been importantly involved in constructing disciplinary power relations points to both the first and third categories. Hunt rightly declines to argue for a single view of law but does not apply this pluralism to Foucault's admittedly fragmented account. Hunt's hypothesis about the efforts of the state to unify law in modern society may provide insight into whether this aspect of Foucault's discussion of law in modern society is also worth retrieving.

Hunt's essay also addresses the gap between Foucault's purely local analysis of power and his global descriptions (like disciplinary society). From Hunt's perspective Foucault's emphasis on local power, while enor-

4. It may be possible to trace historically in the 19th century a process through which law first covered up but later engaged in rationalizing disciplinary power relations. Christopher Tomlins's important study of the disciplinary logic of the "Fellow Servant Rule" shows law covering up discipline during the quickening of the industrial era in America. See Christopher Tomlins, "A Mysterious Power: Industrial Accidents and the Legal Construction of Employment Relations in Massachusetts, 1800-1850," 6 Law \& Hist. Rev. 375 (1988). My own examination of the latter development of the rule suggests that law became a much more active agent of disciplinary intensification during the 1870 s and 1880 s. See Jonathan Simon, "'The Government of Their Servants': The Employers' Duty to Discipline and Govern Work, 1870-1920," Studies in Law, Politics, and Society (forthcoming 1993).

5. "The Sociology of Law," in George Gurvitch \& Wilbur Moore, eds., Readings in Sociology 300 (New York: Random House, 1945). 
mously useful, simply got in the way of studying "the processes that aggregate or condense power in centralized sites" (at 11). Hunt contends that Foucault, while polemically insisting he could do without such an account, actually fell back on an implicit and wholly unanalyzed notion of rulingclass power. Furthermore, Foucault ignored "the significance of the state and other forms of centralized and institutionalized power" (at 11). While Hunt appreciates the reasons for Foucault's avoidance, he forcefully argues that we can bring the state back in while avoiding the temptation to treat it as a purely repressive and perfectly coherent system of power.

To his considerable credit, Hunt directs us away from pondering the internal contradictions in Foucault's various statements about the state and political strategies and argues that research needs something more to account for "the aggregation or globalization of power" (at 14). This "something more" he finds finally not in Foucault but in Poulantzas and Gramsci. Specifically Hunt thinks that research must recognize that the state, while full of contradictions and incoherences, nonetheless represents specific and concrete interests, and must reach for a theoretical understanding of how "a specific discursive constellation comes to be predominant at a given historical juncture" (at 33). Hunt contends that such an approach would allow us to understand resistance better and contribute to transformatory politics (at 8). To accomplish this Hunt wants to abandon Foucault's admittedly halting efforts to develop a nonintentionalistic concept of strategy.

These goals are too attractive to dismiss, but it is important to contemplate what other paths might be open here that would avoid restoring to a central place in our researches the narrative of historical agency which has this persistent habit of turning our attention from the way power is exercised to who has it and what their ends are. ${ }^{6}$ These issues are difficult to resolve in the abstract. ${ }^{7}$ Nonetheless, I want to suggest three brief points on which discussion might continue. First, we can and should study the state but only as site of power, not as a "subject." Second, we should resist the temptation to insist on a research strategy that provides a continuous map of social practices from the micro to the macro level. Finally, it may serve us better intellectually (and ultimately politically) to accept a kind of positivism in Foucault's work that starts off from resistance but never comes around behind it.

Rejecting the state as a "subject" does not have to mean ignoring it. Foucault's evocative image of studying power at its capillary level ends up misleading if it turns one away from looking at state institutions. Capilla-

6. Hunt (at 33) acknowledges that this is a danger in the Gramscian notion of "hegemony" but feels that the risk is worth taking for the added ability to talk about causation.

7. Indeed, Hunc's efforts to clarify the meaning of "strategies" and "projects" and to utilize "structural coupling" are promising but difficult to evaluate without trying them on to see if they help us unpack the logic of specific historical and contemporary practice. 
ries, after all, run even in the brain. His major research imperatives emphasized not the what or who but the where and how of power. We should take Foucault's methodological advice that we study power at its points of application, not as a rule that one avoid the institutional spaces of the state (although he surely says that at times) but that one ask, even of the state, how it exercises power. ${ }^{8}$

Foucault's work on "governmentality," barely begun before his death, represents his effort to turn his methods on the institutions of the state." Foucault recognized that beyond the disciplines, modern society was characterized by technologies of power exercised on the level of whole populations. Governmentality involves the range of practices and discourses through which this power has been problematized and refined. Foucault's research traced its development to discourses of royal pedagogy (a genre of private political theory that dates to at least the Middle Ages), starting in the 16 th century. The rationale of rule expounded in this literature changed then from one founded on the relationship of the prince and his territory to one founded on the prosperity, health, and productivity of the population under his control. ${ }^{10}$ In the last couple of centuries a seemingly analogous shift is visible in political practices. To take one example, the occasions of war have shifted from problems like succession to an explicit concern for markets, resources, and living space.

What is most promising, to my mind, in this late work of Foucault's is not its potential to provide an account of the state, as such, but to direct our attention to technologies of power and to regimes of truth that don't show up at all if one assumes that the disciplinary exercise of power is the primary process of coordination in modern society. ${ }^{11}$

Given the short half-lives of academic trends these days, it may seem that Foucault's emphasis on studying "how power is exercised" has been going on for a boringly long time, and it would be interesting to shift back to weave more coherent and encompassing narratives of agency. Yet the

8. This is, of course, an old insight for sociolegal studies which has long been fascinated (perhaps obsessed) with the broad gap between law on the books and law in action. For Foucault, of course, it is not the gap but the strategic relationship that is most interesting.

9. See generally Graham Burchell, Colin Gordon, \& Peter Miller, eds., The Foucault Effect: Studies in Governmentality (Chicago: University of Chicago Press, 1991).

10. Michel Foucaule, "Governmentality" in id.

11. In Discipline and Punish (Harmondsworth: Allen Lane, 1977), for instance, it seems that such human sciences based on the clinical or medical model as psychoanalysis, sociological criminology, or social work are the most important political discourses in modern society. Foucault's emphasis on populations in the late work fits far more with the observable triumph in the late 20th century of such social sciences as economics, statistical sociology, demography, and operations research. An example of how such an approach might play out in sociolegal research is François Ewald's study of insurance practices and the rationality of risk in modern society. François Ewald, L'Etat Providence (Paris: Grasset, 1986). I cannot agree with Hunt's contention (at 17) that Ewald's analysis suggests no change "in either the form or content of law." 
effort to separate the study of power, including state power, from assumptions about its "subjectivity" continues to go against the grain of our intellectual and political instincts.

It seems to me that the way Foucault organized his studies provides its own valuable guide to how to situate research on power. The carceral archipelago described in Discipline and Punish and the regime of knowledge and direction of the self described in The History of Sexuality, part I, An Introduction, ${ }^{12}$ are both already more or less condensed formations of power made up of various distinct practices, discourses of truth, methods of manipulating bodies, distributions of visibility, etc. Hunt is right that this level of analysis cannot by itself explain why certain formations of power and knowledge come to dominate. But the "history of the present" (as Foucault sometimes called his researches) already knows what dominant formations it is responding to. Abandoning the conceit that theory comes up behind power and tells us whether it is legitimate or why we must resist it is a part of Foucault's polemic relationship with Marx that seems to me worth preserving.

From this perspective, Foucault's quest for an account of strategies without strategists invites us to a kind of "postmodern" (or should one say post-Merton) version of the "middle range." 13 The prison system, the complex of occasions that compel us to give an account of our personal "truths," social insurance-all represent clusters of practices of which we can usefully ask, What is the genealogy of their component techniques? What characterizes their capacities for mobilizing and coordinating their subjects? And what subjectivities (intended or unintended, compliant or rebellious) are constituted as effects of power there?

Foucault's work on governmentality in this way can contribute to what is already a strength in contemporary sociolegal studies, its explorations, at the level of political technologies, of the role of law in the exercise of power, including studies of welfare and social insurance, security and police, constitutional and administrative law, and policy discourse. ${ }^{14}$ Of course, it is always possible, indeed necessary, to link the genealogical analysis of power to analyses of class, gender, and other social relations if one wants to develop a strategic narrative of one's own. But it is precisely the

12. Trans. Robert Hurley (New York: Random House, 1978).

13. Robert K. Merton, Social Theory and Social Structure (New York: Free Press, 1952); William Simon \& John Gagnon, "The Anomie of Affluence: A Post-Mertonian Concept," $82 \mathrm{Am}$. J. Soc. 356 (1976).

14. Joel Handler, The Moral Construction of Poverty: Welfare Reform in America (Newbury Park, Cal.: Sage Publications, 1991); Clifford Shearing \& Philip Stenning, "From the Panopticon to Disneyworld: The Development of Discipline," in A. N. Doob \& E. Greenspan, eds. Perspectives in Criminal Law (Aurora, Ont.: Canada Law Books, 1984); Martin Shapiro, Courts: A Comparative and Political Analysis (Chicago: University of Chicago Press, 1981); Cass Sunstein, "Constitutionalism after the New Deal," 101 Harv. L Rev. 421 (1987); Austin Sarat \& Susan Silbey, "The Pull of the Policy Audience," 10 Law \& Pol'y 97 (1988). 
move of merging these two steps that Foucault mistrusted in those discourses which have laid claim to the status of social sciences.

A final word might be said on the problem of resistance. Start with accepting an apparently unattractive aspect of Foucault's researches. Despite his prodigious personal (and sometimes physical) contribution to resistance (not just in France but in places where intellectuals get more than bad reviews, e.g., Tunisia and Poland), ${ }^{15}$ his works invariably remained more interested in the establishment of power than in the progress of resistance. It is true that he often evoked the essential role of resistance in guiding his studies. (Was it to comfort himself, or us?) But his use of it had a coldly positivist quality. Resistance in his actual studies is like a rock thrown out of the night against a window. It dramatically draws our attention. But the hand of the throwers is never more than fleetingly visible. What we see is the pattern of force lines stretching across a formerly invisible plane-power in its now famous capillary circulation. Foucault rarely looked through the window to the people on the other side whose acts of resistance drew his genealogical gaze.

Therein lies a kind of amorality to genealogical method. It provides a technical knowledge of the practices through which power in a particular time or place is exercised. It does not tell us why it is right to rebel but where and how the institutions that "we" are in (or on or under) are vulnerable. Whether this supplies tactics for "guerrilla war," incremental reform, or total revolution has little to do with genealogical research and much to do with the kinds of "we(s)" that are available to appropriate it. 1991).

15. See Didier Eribon, Michel Foucault (Cambridge, Mass.: Harvard University Press, 
HeinOnline -- 17 Law \& Soc. Inquiry 561992 